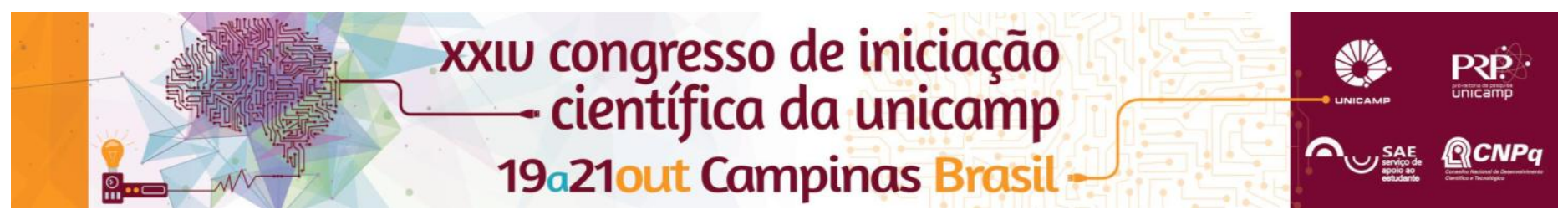

\title{
Digitalização da Biodiversidade do Herbário UEC
}

\author{
Gabriela E. Mello, Gabriela T. Ribeiro.
}

\section{Resumo}

A digitalização do acervo do herbário UEC,coleção de plantas herborizadas, consiste na disponibilização de imagens e descrição da Flora Brasileira e internacional em bases de dados para consulta pública. Os dados dos materiais on-line servem como fonte de pesquisa e consulta para estudos, tanto nos ambientes dos herbários, quanto para pesquisas em geral.

\section{Palavras-chave:}

Informatização, Herbário, Pesquisa.

\section{Introdução}

O Herbário UEC pertence ao Instituto de Biologia da UNICAMP, sendo o segundo maior herbário do Estado de São Paulo, o que o torna referência obrigatória para qualquer trabalho, que envolva plantas brasileiras, em especial das regiões Sudeste, Centro-Oeste e Sul.

A digitalização do Herbário UEC envolve três etapas: coleta do material vegetal, montagem do material coletado e informatização. Neste projeto foram desenvolvidas todas as etapas que são realizadas no herbário, dentre elas: A coleta que consiste em coletar uma amostra da flora, de algum bioma/sistema/região; a montagem que é a etapa na qual se fixa o material herborizado em uma cartolina dando origem à exsicata. A última etapa que é a informatização envolve duas atividades conjuntas, sendo elas, fotografar e informatizar a exsicata (disponibilização das informações e imagens em banco de dados). A informatização da exsicata consiste na digitação da etiqueta de coleta e das imagens capturadas em um programa denominado BRAHMS que funciona também como um banco de dados para uso no acervo. A base de dados para consulta on-line dos materiais informatizados no herbário UEC está disponível no site do INCT - Herbário Virtual da Flora e Fungos (http://inct.splink.org.br/).

\section{Resultados e Discussão}

Toda exsicata recebe um número de registro, um código de barras, e para a captura da imagem é utilizada uma régua para orientar o pesquisador sobre o tamanho das estruturas vegetais. Após cada etapa, a exsicata recebe um carimbo de especificação da etapa em que está processada, informatizada e/ ou fotografada.

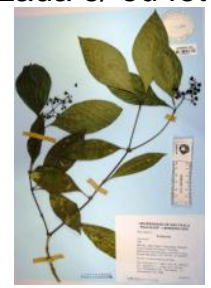

Figura 1. Exsicata montada, informatizada e fotografada.

Grande parte do material informatizado neste projeto foi de coletas de espécimes da família Rubiaceae, como é apresentado na Figura 1, e na Figura 4 estão presentes os gêneros coletados. As coletas informatizadas vieram de estudos realizados em diferentes estados brasileiros (Figura 2).

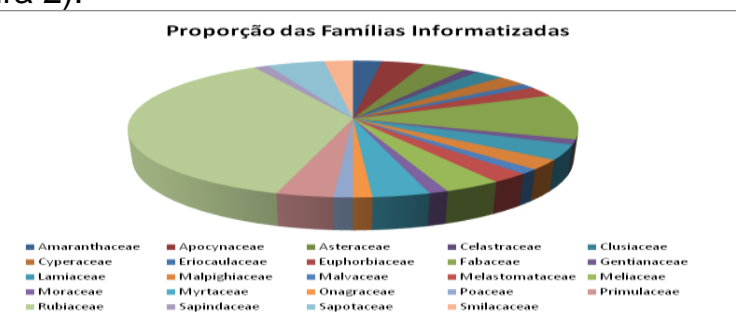

Figura 2. Exsicatas informatizadas de diversas famílias.

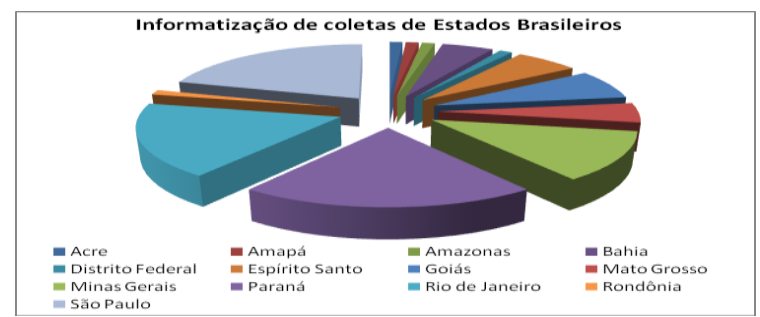

Figura 3. Coletas provenientes de estados brasileiros.

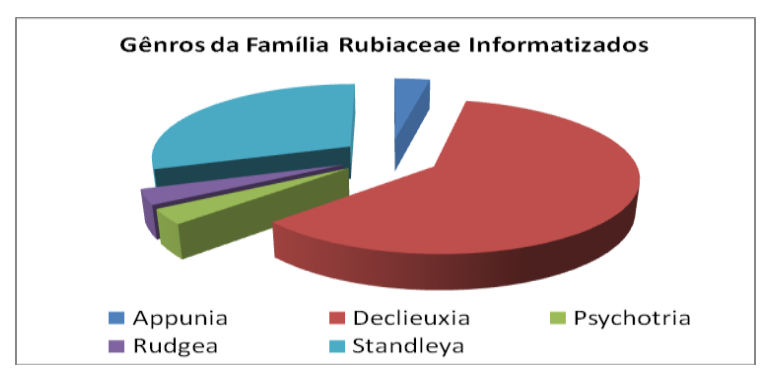

Figura 4. Gêneros informatizados da Família Rubiaceae.

Conclusões

O desenvolvimento deste trabalho possibilitou uma visão completa das atividades que envolvem a rotina de um herbário, além de contribuírem para a evolução das etapas de digitalização do acervo. Possibilitou a disponibilização de significativos dados para acesso online.

\section{Agradecimentos}

Agradecemos à PRP-UNICAMP pela oportunidade de conviver no ambiente universitário durante este ano e ao CNPq pela concessão da bolsa PIBIC-EM. Um agradecimento especial ao Prof. André $\mathrm{O}$. Simões, e às monitoras Lívia Cordi e Kamila Pinheiro de Lima pela dedicação, carinho e atenção. 